\title{
ACTORES SOCIALES DE LA TECNOLOGÍA SIEMBRA DIRECTA. AREA DE DESARROLLO DE LA FACULTAD DE CIENCIAS AGRARIAS. SANTA FE, ARGENTINA
}

\author{
Sandoval, P. ${ }^{1}$; Sanchez, D. ${ }^{1}$; ERBetta, H. ${ }^{1}$; \\ Burgi, N. ${ }^{1}$; LAuXManN, S. ${ }^{1}$; AlbreCht, A. ${ }^{1}$; \\ Jimenez Lucena, M. A. ${ }^{1} ;$ Motto, J. L. ${ }^{2}$ \& GargiceVich, A. ${ }^{3}$
}

\begin{abstract}
RESUMEN
La siembra directa fue desarrollada en Estados Unidos y Europa en la década del 40, debido al deterioro de los suelos. Basada en la nula remoción y el alto uso de fertilizantes y plaguicidas.

En Argentina ha sido ampliamente difundida por instituciones privadas y públicas. Fue adoptada masivamente por agricultores y luego por ganaderos, desplazando a las tecnologías convencionales y avanzando hacia áreas no aptas para la agricultura. La sustentabilidad agropecuaria (marco donde surge la siembra directa), aparece en el centro de una compleja convergencia de intereses sociales, ecológicos y tecnológicos, siendo el cambio tecnológico un fenómeno multidimensional y complejo. Para realizar el presente estudio debió hacerse un "recorte de la realidad”. Se usó metodología cualitativa para elaborar un mapa de actores sociales de la siembra directa, en la zona de la Facultad de Ciencias Agrarias de Esperanza. Se obtuvo un estudio explicativo del aspecto social de esta innovación, con la finalidad de suministrar fundamentos teóricos para el diseño de estrategias de desarrollo rural.
\end{abstract}

Palabras claves: innovación tecnológica, siembra directa, actores sociales.

\section{SUMMARY}

Direct sowing technological innovation social actors and their relationships. The case of the development area Faculty of Agrarian Sciences, Esperanza, Santa Fe, Argentina.

Direct sowing, conceptualized inside the sustainable technologies, arises as answer to the floors deterioration problem. It was developed almost simultaneously in United States and Europe (the 40 decade). Based on the null removal of the floor, with high fertilizers, insecticides and herbicides

1.- Facultad de Ciencias Agrarias de Esperanza, Universidad Nacional del Litoral. Proyecto CAID 2000.

$\mathrm{N}^{\circ} 123$. Expediente $\mathrm{N}^{\circ} 396.004 / 339$.

2.- Profesional independiente. Asesor técnico privado, Argentina.

3.- INTA. Instituto Nacional de Tecnología Agropecuaria, Argentina. 
use.

In our country it has been broadly diffused by private and also public institutions. It was massively adopted by agricultural farmers; and today also for cattlemen, displacing this way to the conventional technologies and advancing toward areas not capable previously for the agriculture.

The agricultural sustentability (where direct sowing arises), appears in the center of a convergence complex of social, ecological and technological interests. Keeping in mind that technological change is a complex and multidimensional phenomenon, that takes to make a "clips of the reality" to be able to study it, have been worked in the construction of a social actors map, related with direct sowing, in the development area Faculty of Agrarian Sciences, Esperanza. Using qualitative type methodology, the actors will be identified and will be characterize their interrelations. The final product will be an explicative and detailed study in the social aspect, about this technological innovation, with the purpose of giving theoretical foundations for the design of strategies or rural development projects.

Key words: technological innovation, direct sowing, social actors. 